RESIDENT

\& FELLOW

SECTION

Section Editor

Mitchell S.V. Elkind,

MD, MS

Donghoon Oh, MD, MS Seong-Ho Park, MD, $\mathrm{PhD}$

Address correspondence and reprint requests to Dr. Seong-Ho Park, Department of Neurology, Seoul National University College of Medicine, Seoul National University Bundang Hospital, 300 Gumi-dong, Bundang-gu, Seongnam-si, Kyeonggi-do, 463 707, South Korea nrpsh@snu.ac.kr

\title{
Teaching NeuroImages: \\ MRI in Ramsay-Hunt syndrome after trigeminal zoster
}

\section{Figure 1 Photograph of patient with right facial mandibular distribution zoster}

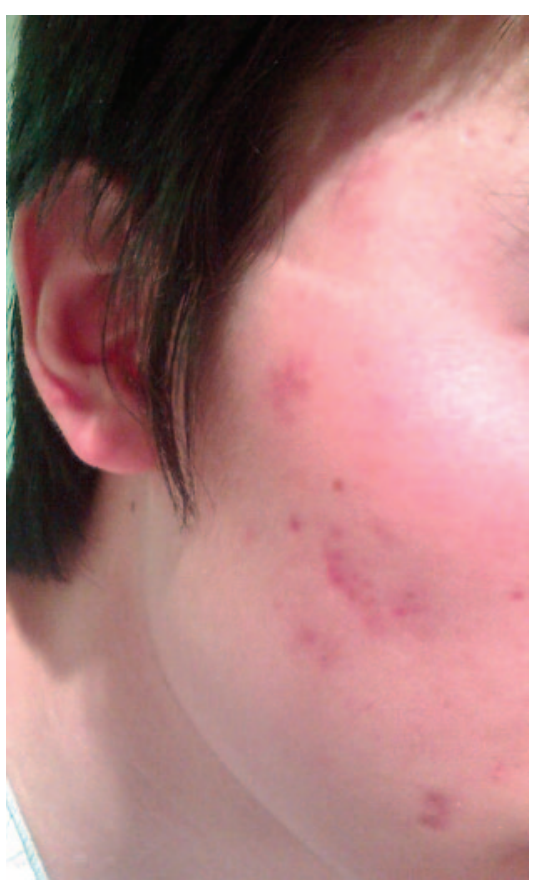

A 22-year-old man developed painful tongue swelling, a right facial rash, and right lower motor neuron facial palsy over 2 weeks. On examination he had a vesicular rash in a mandibular distribution and on the concha of the right earlobe, and right peripheral facial palsy (figure 1). T2-weighted MRI revealed high signal intensity in the spinal trigeminal tract (figure 2, A and B), and T1-weighted gadoliniumenhanced MRI revealed right facial nerve enhancement in the labyrinthine segment (figure 2C). MRI findings of spinal trigeminal nucleus and tract involvement in trigeminal zoster, ${ }^{1}$ and of facial nerve enhancement in Ramsay-Hunt syndrome, ${ }^{2}$ have been reported. Our patient developed trigeminal zoster and Ramsay-Hunt syndrome sequentially, and we confirmed corresponding abnormalities on MRI.

\section{REFERENCES}

1. Aribandi M, Aribandi L. MRI of trigeminal zoster. Neurology 2005;65:1812.

2. Tada Y, Aoyagi M, Tojima H, et al. Gd-DTPA enhanced MRI in Ramsay Hunt syndrome. Acta Otolaryngol Suppl 1994;511:170-174.

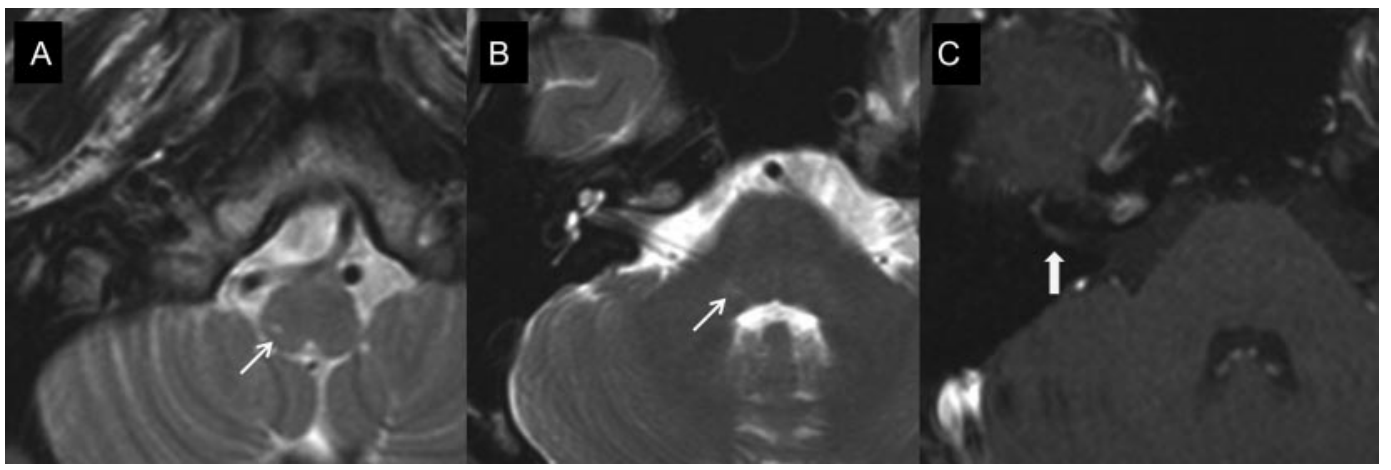

Axial T2-weighted MRIs show high signal intensity in the right lower pons and medulla posteriorly and laterally (A, B) (arrows) corresponding to the location of the spinal trigeminal tract. Axial T1-weighted gadolinium-enhanced MRI reveals right facial nerve enhancement in the labyrinthine segment (C) (arrow). 


\section{Neurology}

\section{Teaching NeuroImages: MRI in Ramsay-Hunt syndrome after trigeminal zoster Donghoon Oh and Seong-Ho Park}

Neurology 2010;74;e33

DOI 10.1212/WNL.0b013e3181d25b4a

\section{This information is current as of March 1, 2010}

\section{Updated Information \&} Services

References

Subspecialty Collections

Permissions \& Licensing

Reprints including high resolution figures, can be found at: http://n.neurology.org/content/74/9/e33.full

This article cites 2 articles, 1 of which you can access for free at: http://n.neurology.org/content/74/9/e33.full\#ref-list-1

This article, along with others on similar topics, appears in the following collection(s):

All Clinical Neurology

http://n.neurology.org/cgi/collection/all_clinical_neurology

MRI

http://n.neurology.org/cgi/collection/mri

Viral infections

http://n.neurology.org/cgi/collection/viral_infections

Information about reproducing this article in parts (figures,tables) or in its entirety can be found online at:

http://www.neurology.org/about/about_the_journal\#permissions

Information about ordering reprints can be found online:

http://n.neurology.org/subscribers/advertise

Neurology ${ }^{\circledR}$ is the official journal of the American Academy of Neurology. Published continuously since 1951, it is now a weekly with 48 issues per year. Copyright . All rights reserved. Print ISSN: 0028-3878. Online ISSN: 1526-632X.

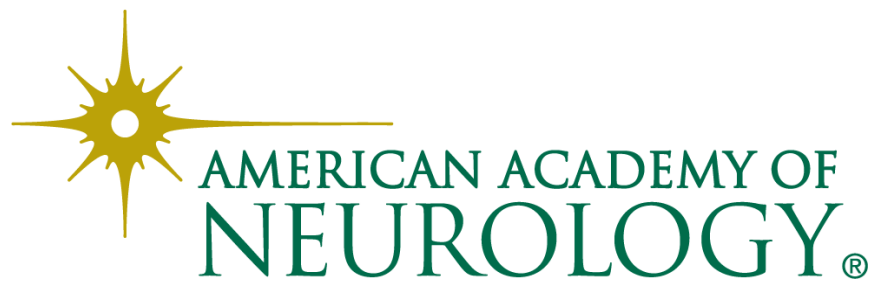

